Susan M. Allen

\title{
Why ACRL needs a dues increase Support the association in the 21st century
}

A

CRL's finances can be likened to a three-

legged milking stool. The association has revenue and expenses in three areas: membership services, publications, and educational programs. Historically, the cost of membership services has been greater than the revenue generated for these services, that is, ACRL dues. At the same time, ACRL publications (CERL and CERL News) generated a surplus from advertisement revenues-both product ads and classified ads. This income paid production costs for the publications and helped pay for membership services. Revenues generated by registration and other fees for educational programs (including the ACRL National Conference) have always been budgeted conservatively in order to guarantee that they break even or end in the black. Any surpluses generated by educational programs also helped cover the gap between the expenses and revenue of member services.

The last several years have seen a shift in the financial landscape of ACRL, most notably resulting in a widening gap between revenues generated from member services revenue (primarily dues) and the actual funds spent to provide member services. This shift has thrown our three-legged stool off balance. The proposed dues increase on this year's ballot is the result of much thoughtful exploration of ACRL's financial situation and is put forward as a solution that will allow the association to regain a balance in it's revenue streams and continue to support its members through the many programs and services that these revenues sustain.

\section{Membership services expenses outpace revenues}

In 1989, the last time dues were increased, 29 percent of ACRL's revenue was coming from dues while basic membership services amounted to 38 percent of the expenses of the association. Unfortunately, the gap between dues revenue and member services has grown in recent years. In FY 2004 ACRL spent $\$ 725,000$ on member services and brought in only slightly more than $\$ 500,000$ in dues revenue, donations, and awards income. In other words, member services expenses are now 50 percent higher than

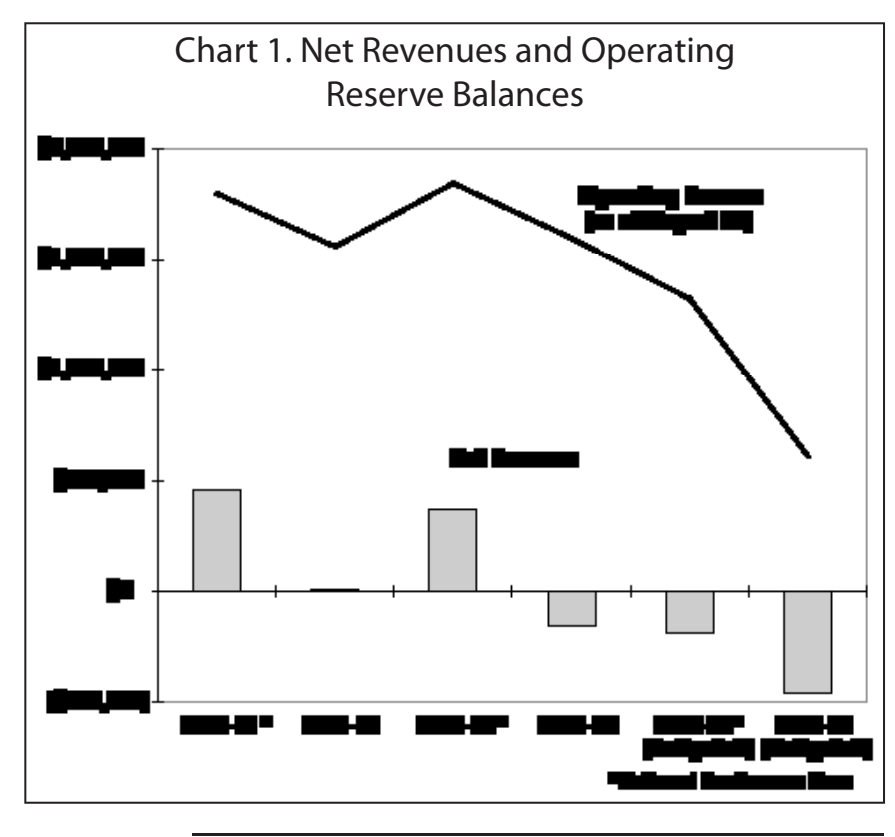

Susan M. Allen is chief librarian at the Getty Research Institute and chair of the ACRL Budget and Finance Committee, e-mail: sallen@getty.edu.

(c) 2005 Susan M. Allen 
member services income. The "Member services revenues to expenditures" table and the "Executive Summary 2003-2004" of the budget in my financial report for FY 2004 show the gap growing over the last four years. ${ }^{1}$ Chart 1 shows this relationship through FY2006.

\section{Surplus publications revenue declining}

Historically, surplus revenue generated by CERL and CERL News has been used to bridge the gap between member services revenue and expenses, allowing ACRL to continue to broaden its programs and services. However, during the past several years in which we've seen the gap widen, revenues from CERL and CERL News have also declined and are no longer generating surplus revenue. (See the decline for CERL and CERL News revenues from 2000-2006 in Chart 2.) This means that both publications are beginning to run deficits, and they no longer provide a cushion or surplus to address the gap between member services and dues revenue. The three-legged stool that always sat firmly on at least two of its three legs, now stands on only one leg: educational programs. Currently, ACRL's educational programs are the only activities of ACRL without a negative gap between expenses and revenues. It is just too risky for ACRL to continue to function balanced pre-

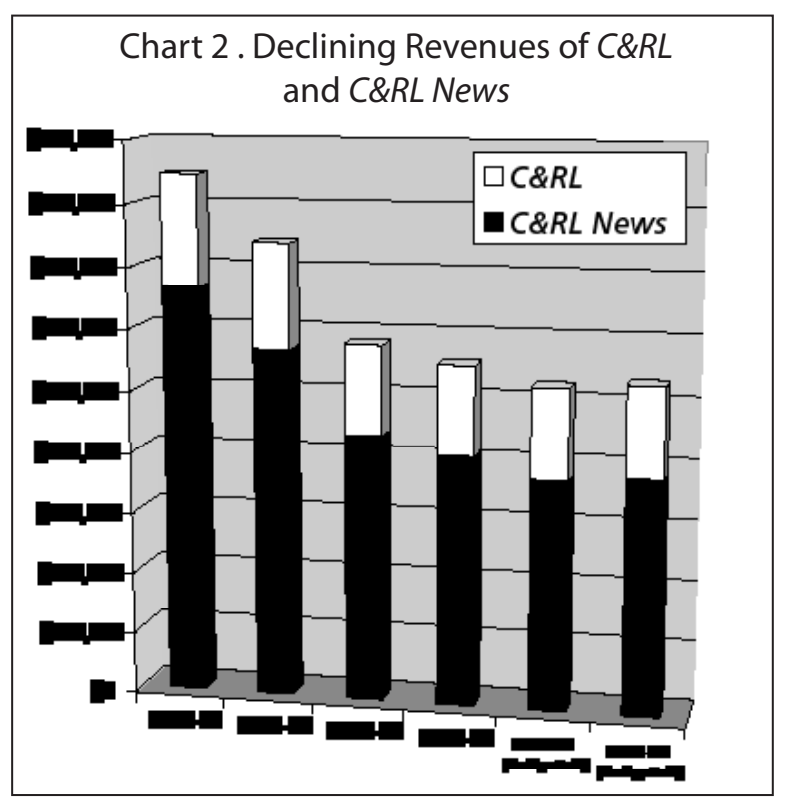

cariously on this single leg of the stool. One only need think of how SARS devastated the ALA Annual Conference in Toronto just a few years ago to understand why the association must not depend completely on the revenues generated from its educational programs to support everything else it does.

\section{Dues increase recommended}

To keep ACRL on a firm financial footing and to avoid cutting important member services, the ACRL Budget and Finance Committee decided that it was prudent and timely to consider a dues increase. (Dues increases last occurred in 1982 and 1989.) The committee carefully studied and discussed ACRL budgets and trends in recent years. The committee also considered ACRL's reserve fund, which has been tapped to sustain programs during time of revenue shortfall. ALA policy mandates that divisions keep a reserve equal to 25 percent of the average of the last four years' operating expenses. Budget projections put ACRL very close to this minimum mandated reserve. As shown in Chart 3, when expenditures are greater than revenues for the year, the reserve is depleted. At the ALA Midwinter Meeting in January 2004, the Board received the recommendation from the Budget and Finance Committee that dues be increased. The Board discussed the recommendation over the next five months, and in June 2004 at the ALA Annual Conference voted its intent to approve a resolution regarding a dues increase for placement on the spring 2005 ballot. The ACRL by-laws require such a vote of the membership to change the amount of member dues. The Board shared this intent with the members after the Annual Conference and asked for comments and suggestions.

At the ALA Midwinter Meeting in January 2005, the Board approved a dues increase resolution. The resolution calls for an increase in annual dues from \$35 to $\$ 45$ the first year (2006) and \$55 thereafter. (This phased-in dues increase plan was developed in response to member comments.) Annual dues for personal members 
who are full-time students or retirees will be set at $\$ 35$. This resolution will be placed on the spring 2005 ballot and the full membership will have the opportunity to vote on the increase. Currently, all divisions of ALA have regular member dues set between $\$ 40$ and $\$ 60$ (LAMA offers a first-year member rate of $\$ 35$; subsequent years are \$50). Furthermore, in January the ACRL Board increased organizational member dues to $\$ 110$ from $\$ 90$ (organizational dues do not have to be set by a vote of the membership).

\section{The full value of ACRL membership}

The most compelling reason to vote for the dues increase is to support member services. Listed below are many of the important member services activities we have come to expect as members of ACRL. With the additional revenue generated by a dues increase, ACRL will be able to continue to provide these vital resources and opportunities:

- Information not found elsewhere. ACRL sets a high standard for its resources and emphasizes quality in its knowledge, products, and services. ACRL members can access print and electronic copies of $C \xi R L$ (bi-monthly), CERL News (11 times/year), and two newsletters from sections of their choice to keep them up-to-date with the latest developments in the field. Subscriptions to these publications alone cost far more than the proposed membership dues.

- A unique community. ACRL provides the community and connections to help you throughout your career and perhaps your lifetime. ACRL is the source for the personal and professional relationships that make the academic or research librarian profession more rewarding. Through committee service and electronic discussion lists (and soon online communities), ACRL provides

you with virtual connections to colleagues around the globe who share your interests. ACRL offers 17 distinct sections to address your interests.

- Support for our profession. ACRL and our members help academic and research libraries pursue a broad agenda, ensuring that their roles are understood, valued, and protected by other stakeholders. ACRL and its members set standards for library services and programs that create benchmarks for the profession. ACRL also develops toolkits to help librarians convey key messages about the value of libraries to their communities. ACRL has been active in advancing the discussion of scholarly communications issues and the importance of information literacy to learning. 
- A chance to grow, learn, and advance. ACRL gives you the skills to make a difference. The organization is dedicated to developing members who are recognized as flexible, dynamic, and progressive leaders in their institutions and in scholarly communities. ACRL offers a wide variety of learning opportunities, both virtual and face-to-face; career resources; and mentorship programs, as well as opportunities to speak, to lead, and to publish. Participating in these activities helps advance the profession and can help your career. Don't forget that ACRL members enjoy substantial discounts on registrations for institutes, workshops, preconferences, e-learning, and the National Conference. ACRL also offers thousands of dollars worth of scholarships to selected ACRL events each year.

- Recognition and professionalism. ACRL, the preeminent professional organization in the field, provides the recognition you and your library deserve. Membership in ACRL fosters professionalism and provides valuable exposure and experience for individual members and their libraries through publications, conference presentations, and awards programs.

\section{Benefits of ALA membership}

Some readers may wonder why it is necessary to pay ALA member dues as well as ACRL member dues when they are only interested in the professional development opportunities of ACRL. To understand this, the legal positions of ALA and ACRL must be understood. ALA exists as a legal entity. ACRL is a division of ALA, and as such, ACRL does not exist independently as a legal entity. This relationship is much like the relationship of ACRL sections to ACRL. ALA provides a number of critical services to its divisions. Some are quite visible like the ALA Annual Conference and Midwinter Meeting, publications, the Washington office, and lobbying for and against such public policy issues/legislation as LSTA funding and the USA PATRIOT Act. ALA offers the opportunity to be part of one unified voice for librarians, which is heard much more clearly than many, smaller disparate groups.
ACRL has kept dues the same for 16 years, partly because of support from ALA, much of which is not readily visible to the average ACRL member, including human resources, legal services, accounting, technology support, public information and promotion, the Washington Office for advocacy, membership processing, library services, production of the Handbook of Organization, and office space, furniture, utilities, and equipment in a well maintained building. ALA also pays for all meeting and program space for ACRL events at ALA Annual Conference and Midwinter Meeting.

If ACRL were to try to stand alone without "big" ALA, its member dues would have to be many, many times more costly than the dues increase currently proposed.

\section{Questions and answers}

The ACRL Board has drawn up a list of 16 frequently asked questions and provided answers to them to help you better understand the proposed dues increase. The "ACRL Dues FAQ" has been included on the following pages for your convenience and will also be sent to you with your ballot. It supplies additional clarification of the need for a dues increase. Please read the "FAQ" thoroughly as it augments in great detail the arguments that I have only been able to outline in this article.

\section{Vote yes for the dues increase}

In April 1989, during the period when the last ACRL member dues increase was on the ballot, an article appeared in CERL News entitled "Why ACRL members should vote to increase their dues." ${ }^{2}$ In the article, Linda J. Piele, then chair of the ACRL Budget and Finance Committee, concluded with a compelling appeal to vote for a dues increase. Her words are as applicable today as they were in 1989. She argued: "After a period of several years during which revenues ... increased nicely each year, ACRL is entering a period of tougher financial times. Increases in revenues have flattened out, while costs continue to increase ... just as they do in our libraries.

(continued on page 187) 


\section{ACRL DUES FAQ}

This document is intended to clarify the details of a proposed dues increase whereby ACRL dues will increase from $\$ 35$ to $\$ 45$ for one year (2006) and $\$ 55$ thereafter. Annual dues for personal members who are full-time students or retirees shall be set at $\$ 35$.

\section{When was the last dues increase?}

ACRL dues have been unchanged since 1989 when the last dues increase was approved.

\section{Why hasn't ACRL raised dues for 15 years?}

ACRL works hard to deliver member services without an increase.ACRL's Budget and Finance Committee reviews dues revenue and membership services costs annually and has raised the issue of a dues increase with the Board several times in the past 15 years. Because of dwindling higher education funding, previous Boards elected to rely on nondues revenue (e.g., revenue from classified ads, subscriptions, and national conferences) to support member services, rather than asking members to pay more in dues. But, based on the economic realities of today, these revenue streams are no longer adequate.Tighter economics across academia mean revenues from ACRL publishing programs (including job ads, product ads, and subscriptions) are declining and no longer make up the revenue shortfall. Because libraries have less to spend with vendors, these vendors spend less on advertising and corporate donations, which increases our reliance on dues revenue to support member services.

\section{Why ask for a dues increase now?}

Consider your expenses in 1989. Few goods and services are still priced at 1989 levels. Due to inflation, it now costs $\$ 53.43$ (in 2004 dollars) to provide the same services that $\$ 35$ provided in 1989 dollars. While dues have remained constant, programs and services have expanded, including:

- Information literacy initiatives endorsed by the higher education community

- Scholarly communication advocacy and education

- Outreach to higher education groups

- Promotion of academic and research libraries and librarians through the @ your library campaign

- A recruitment video for the profession

- More awards (which require administrative support from the association)

- Scholarships

- Annual library trends and statistics report

- Mentor program for Spectrum Scholars

- Electronic versions of ACRL's journals and serials, and

- An information-rich ACRL Web site.

None of these services generate revenues because they are provided strictly as member services. They are supported by member dues and surplus revenues from other ACRL activities, primarily publishing. But dues no longer cover the expenses for these membership services activities. You can easily see that member services expenses outstrip dues revenues by almost $50 \%$. 


\begin{tabular}{|c|c|c|}
\hline Fiscal Year & Member Services Expense & Dues Income \\
\hline 2004 Actual & $\$ 725,022$ & $\$ 506,688$ \\
\hline 2005 Budgeted & $\$ 1,007,914$ & $\$ 503,454$ \\
\hline
\end{tabular}

\section{Doesn't ACRL get funding from ALA?}

No.ACRL does not receive any income from ALA.According to the operating agreement between ALA and its divisions, all ACRL programs and services are supported by revenues that ACRL earns through dues, publishing, donations, and educational programs.

\section{What exactly will I get for my dues payment?}

You receive the full value of ACRL membership with resources and opportunities that exist nowhere else:

- Information not found elsewhere. ACRL sets a high standard for its resources and emphasizes quality in its knowledge, products, and services. ACRL members can access print and electronic copies of College and Research Libraries (bi-monthly), College and Research Libraries News (11 times/year), and two newsletters from sections of their choice to keep them up-to-date with the latest developments in the field. Subscriptions to these publications alone cost far more than the proposed membership dues.

- A unique community. ACRL provides the community and connections to help you throughout your career and perhaps your lifetime. ACRL is the source for the personal and professional relationships that make the academic or research librarian profession more rewarding. Through committee service and electronic discussion lists (and soon online communities), ACRL provides you with virtual connections to colleagues around the globe who share your interests.

- Support for our profession. ACRL and our members help academic and research libraries pursue a broad agenda, ensuring that their roles are understood, valued, and protected by other stakeholders.ACRL and its members set standards for library services and programs that create benchmarks for the profession. ACRL also develops toolkits to help librarians convey key messages about the value of libraries to their communities.

- A chance to grow, learn and advance. ACRL gives you the skills to make a difference. The organization is dedicated to developing members who are recognized as flexible, dynamic, and progressive leaders in their institutions and in scholarly communities. ACRL offers a wide variety of learning opportunities, both virtual and face-to-face; career resources; and mentorship programs, as well as opportunities to speak, to lead, and to publish. Participating in these activities helps advance the profession and can help your career. Don't forget that ACRL members enjoy substantial discounts on registrations for institutes, workshops, preconferences, e-learning, and the National Conference.

- Recognition and professionalism.ACRL, the preeminent professional organization in the field, provides the recognition you and your library deserve. Membership in ACRL fosters professionalism and provides valuable exposure and experience for individual members and their libraries through publications, conference presentations, and awards programs.

\section{Will I receive any new benefits as a result of the dues increase?}

Yes. By supporting a dues increase, you will enable ACRL to maintain its current programs and increase advocacy efforts, increase venues for scholarship, provide additional opportunities for virtual and hands-on professional development, increase scholarships, and provide seed money for new initiatives. 


\section{Why not simply cut expenses?}

There is nothing left to trim.ACRL's Budget and Finance Committee reviews the budgets each year and has grown increasingly concerned about the way expenses are outstripping revenues. ACRL carefully monitors its budgets and makes cuts wherever possible without reducing member services.Vacated positions are not immediately filled to realize some salary savings, purchases of all but essential supplies are postponed, and travel is undertaken only after careful consideration and exploration of the most cost-effective options.ACRL's budget expenses are used to fund the programs that members told ACRL they wanted-scholarly communication, information literacy, standards, section newsletters, sections and committees, awards, programs at ALA conferences, scholarships, CERL, CERL News, advisory services, etc. There really isn't any excess in the budget. If a dues increase does not pass, the ACRL Board will have to consider carefully which member programs and services to discontinue.

\section{Doesn't the National Conference generate enough revenue to support ACRL's programs?}

While ACRL does not keep any portion of the revenue generated by the ALA Annual and Midwinter meetings, the biennial ACRL national conference does provide income for the division. To keep registration fees as low as possible, ACRL does not budget for large surplus revenue from the National Conference.ACRL continues to hear from librarians in the field that travel budgets are being tightened and/or frozen.As a result, it seems prudent to budget conservatively when estimating the number of librarians who will register for the conference.The revenue that traditionally supports the conference (exhibit fees, registration fees, donations) may also be considerably reduced as budgets at libraries and corporations are tightened. In addition, factors beyond ACRL's control (SARS, 9/11, etc.) may affect conference attendance. ACRL realizes that it must budget conservatively in the event that an unexpected occurrence should affect attendees' ability to travel to the conference.

\section{I've heard that ACRL has a large reserve and an endowment? Why not spend those instead of raising dues? \\ Just as your institution has an endowment,ACRL has a long-term investment fund (LTI). ACRL has started spending the interest from this LTI to support new initiatives. But, just as your institution does not allow the principal to be spent, ACRL needs to preserve its principal for its long-term viability.ACRL also has a reserve fund that has been tapped to sustain programs during times of revenue shortfall. ALA policy mandates that divisions keep a reserve equal to $25 \%$ of the average of the last four years' operating expenses.}

\section{Why do I have to join ALA to belong to ACRL?}

ACRL was formed within ALA in 1938 to provide academic and research librarians a forum for working together on topics of special interest. ACRL is a division of the ALA and does not exist independently. ACRL services are intertwined with ALA services, and there are economies realized by being part of a larger organization.ACRL dues would be considerably higher without the services provided through the ALA infrastructure.

11. What value does ALA provide? My primary interest is in academic issues.

There is great value to ACRL and ACRL members from belonging to ALA. ACRL has kept dues the same for 16 years, partly because of support from ALA, including human resources, legal services, accounting, technology support, public information and promo- 
tion, the Washington Office for advocacy, membership processing, library services, and office space and utilities.ALA also pays for all meeting and program space for ACRL events at ALA Annual Conferences and Midwinter Meetings.

More importantly, however, ALA offers the opportunity to be part of a unified voice for librarians, which is heard much more clearly than many smaller disparate groups.As members of ALA,ACRL members join librarians working in all types of libraries to address issues that cut across the profession. Recently ACRL worked with ALA to launch a "Campaign for America's Libraries" focused on academic and research libraries. This included consumer research to develop key messages that would resonate with academic and research libraries' stakeholders about the value of their libraries and library services. A toolkit was created to help librarians convey these key messages to their stakeholders. This recent effort built on a project already undertaken by ALA. ACRL's advocacy voice is strengthened through the representation it receives from ALA in Washington, D.C.ALA has led the effort to protest sections of the USA PATRIOT Act, and sought support for funding for legislation such as LSTA and HEA. Attempting to separate academic issues from those of interest to all librarians is neither feasible nor cost effective.

\section{Are ACRL's proposed dues in line with what others charge?}

Yes. You can see below how ACRL compares with other ALA divisions.

\begin{tabular}{|c|c|c|c|}
\hline Division & Regular Dues & Student Dues & Other Categories \\
\hline AASL & $\$ 40$ regular & $\$ 15$ student & $\$ 20$ retirees \\
\hline ACRL & $\begin{array}{c}\$ 35 \text { regular; proposed } \$ 45 \\
\text { regular for one year }(2006) \\
\text { and } \$ 55 \text { thereafter }\end{array}$ & $\begin{array}{l}\text { \$35 for full time } \\
\text { students }\end{array}$ & $\$ 35$ retirees \\
\hline ALCTS & $\$ 55$ regular & $\$ 15$ student & \$25 library support staff \\
\hline ALSC & $\$ 45$ regular & $\$ 18$ student & \\
\hline ALTA & $\$ 50$ regular & & \$25 library advocate \\
\hline ASCLA & $\$ 40$ regular & \$15 student & $\$ 15$ retiree \\
\hline LAMA & $\begin{array}{l}\$ 35 \text { first year; } \$ 50 \text { 2nd } \\
\text { and later years }\end{array}$ & $\$ 15$ student & \\
\hline LITA & $\$ 60$ regular & \$25 student & \\
\hline PLA & $\$ 50$ regular & $\$ 10$ student & $\begin{array}{c}\$ 40 \text { retiree, inactive or } \\
\text { non-salaried }\end{array}$ \\
\hline RUSA & $\begin{array}{c}\$ 45 \text { regular } \\
\text { (proposing increase to } \$ 60 \\
\text { on } 2005 \text { ballot) }\end{array}$ & $\begin{array}{l}\$ 20 \text { student } \\
\text { (proposing in- } \\
\text { crease to } \$ 25 \text { on } \\
2005 \text { ballot) }\end{array}$ & \\
\hline YALSA & $\$ 40$ regular & $\$ 15$ student & \\
\hline
\end{tabular}

ACRL's proposed dues increase is in line with the range of dues from $\$ 40$ to $\$ 60$. But ACRL is the only division that provides all dues-paying members four publications: $C E R L$ ( 6 times/ year scholarly research journal), CERL News (11 times/year news magazine), and two section newsletters (2 times/year) for the two free sections included in ACRL membership. 


\section{Who approves a dues increase?}

ACRL members approve a dues increase. Here is how the process works:

1. The Budget and Finance Committee (B\&F) annually reviews the association's revenue streams and expected expenses. When B\&F decides there is a need for additional dues income, it makes a recommendation to the Board.

2. The Board considers the recommendation. The Board received the B\&F recommendation at Midwinter 2004 and discussed it over the next five months. At the 2004 Annual Conference, the Board voted their intent to approve a resolution regarding a dues increase for placement on the spring 2005 ballot.

3. The Board approved a dues increase resolution at Midwinter 2005.

4. The resolution will be placed on the spring 2005 ballot and the full membership will have the opportunity to vote on the dues increase.

\section{Why not increase dues all at once? Why phase it in over two years?}

ACRL is proposing a multi-phase dues increase in an effort to ease the burden on our members. The Board originally considered approving a $\$ 20$ increase in one year but when the Board asked members for feedback, many expressed a desire to phase in the increase over two years. The Board responded to this request and approved the proposed increase in annual dues from $\$ 35$ to at $\$ 45$ for one year (2006) and $\$ 55$ thereafter, except that the annual dues for personal members who are full-time students or retirees shall be set at $\$ 35$.

\section{When would this proposed dues increase go into effect?}

If the dues increase is approved, it would go into effect in ALA fiscal year 2005-2006, with the new dues amount put in the renewal notices that ALA sends beginning in September 2005.

\section{How long would the new dues structure stay in effect?}

The dues proposal does not establish a time limit. However, the Board agrees with the Budget and Finance Committee that it is prudent to regularly monitor expenses and revenue streams. While additional changes to the dues structure are not imminent, it is likely that the organization will not allow another 15 years to pass before dues are reviewed and perhaps adjusted. The Board will regularly review dues revenues as a part of reviewing the overall budget.

("Why ACRL needs..." continued from page 182)

Unless some action is taken, the budget will be seriously out of balance ... and we will have to start drawing down the reserve fund below the level mandated..." She continued, "In order to be strong, ACRL needs to operate on a sound financial basis." And She concluded, "The Budget and Finance Committee urges you to vote to maintain the services ACRL currently provides. If you agree that the issues and opportunities which academic and research librarians face require a strong ACRL, you will join us in voting for a dues increase." I couldn't say it better!

\section{Notes}

1. See CERL News 65, no. 11 (2004): 704-708).

2. Linda J. Piele, "Why ACRL Members Should Vote to Increase Their Dues," CERL News, 50, no. 4 (1989): 297. 